lower upper limit will limit blood supplies. ${ }^{6}$ People who repeatedly show increased aminotransferase concentrations according to the lowered normal upper limit should be further investigated by serum biochemistry, viral marker tests, and ultrasonography. The cost effectiveness of this approach still needs to be evaluated prospectively in various settings.

\section{Strength and weakness}

This study has several strong points. Firstly, it was performed with a large population (142 055 people) and had a long follow up period (eight years). Previous studies have had a cross sectional design or short follow up period, and they failed to investigate the association between serum aminotransferase concentration and long term mortality. ${ }^{27-9}$ Secondly, the results can be generalised to the broader Korean population and, perhaps, to other populations as well. While previous studies investigated special populations, such as blood donors and haemodialysis patients, our study cohort was recruited from the nationwide general population. ${ }^{2-9}$ Thirdly, the use of repeated measurements of variables decreased the possibility of measurement error or misclassification bias. Finally, to increase the validity of the causes of death, we verified morality from liver diseases by reviewing data on hospital admissions.

Potential limitations of this study include the brief information on pre-existing diseases, lack of other laboratory tests for liver diseases, and nonstandardised aminotransferase assays. Firstly, as the objective medical history of the study population was not available, we used the information provided by participants. We excluded people who indicated that they had any previously known diseases. We also assessed the confounding effects of unknown preexisting disease by comparing the results by different follow up periods and found no association. Secondly, we did not study viral marker or perform liver function tests other than aminotransferase assays in the baseline examination. Individuals with family history of liver disease are at high risk of the chronic hepatitis B virus infection because the infection is common in Korea, $5-10 \%$ in men and $1-5 \%$ in women, and transmitted horizontally in high frequency. ${ }^{11}{ }^{11}$ We assessed the effects of the family history of liver disease using a stratified analysis. The results showed that family history of liver diseases did not alter the outcome of the study. Thirdly, 419 hospitals over the country conducted the health examination and the serum aminotransferase assay was not standardised. All hospitals, however, followed the internal and external quality control procedures as stipulated by the Korean Society of Quality Control in Clinical Pathology. The misclassification bias, if any, is likely to be nondifferential reduction of the relative risk. Hence, the results are unlikely to be distorted by measurement error.

\section{Conclusion}

Our findings indicate that serum aminotransferase concentration is associated with mortality from liver disease, even within the current normal range. The adjustment of the normal limit of serum aminotransferase may be necessary, especially in populations in which liver diseases are common.

\section{What is already known on this topic}

The serum aminotransferase test with upper normal limit of $40 \mathrm{IU} / 1$ can identify liver damage

Little is known about the association between the normal range of the serum aminotransferase concentration and mortality

\section{What this study adds}

Serum aminotransferase concentration, even under $40 \mathrm{IU} / \mathrm{l}$, is positively associated with mortality from liver disease

The sensitivity of the serum aminotransferase test with the current normal range is low in identifying individuals at risk of death from liver disease

Lowering the normal range of the serum aminotransferase concentration is advisable in populations in which liver diseases are common

We thank the National Health Insurance Corporation (former the Korea Medical Insurance Corporation) for providing the data. Contributors: See bmj.com

Funding: Supported, in part, by a grant from the 21C Frontier Functional Human Genome Project of the Ministry of Science and Technology of Korea.

Competing interest: None declared.

Ethical approval: Institutional review board of Severance Hospital at Yonsei University.

Pratt DA, Kaplan MM. Evaluation of abnormal liver-enzyme results in asymptomatic patients. N Engl J Med 2000;342:1266-71.

2 Prati D, Taioli E, Zanella A, Torre ED, Butelli S, Del Vecchio E, et al. Updated definitions of healthy ranges for serum alanine aminotransferase levels. Ann Intern Med 2002;137:1-9.

3 Salvaggio A, Periti M, Miano L, Tavanelli M, Marzorati D. Body mass index and liver enzyme activity in serum. Clin Chem 1991;37:720-3.

Piton A, Poynard T, Imbert-Bismut F, Khalil L, Delattre J, Pelissier E, et al. Factors associated with serum alanine transaminase activity in healthy subjects. Hepatology 1998;27:1213-9.

Guzzanoli G, Grugni G, Minocci A, Moro D, Morabito F. Liver steatosis in juvenile obesity. Int J Obes 2000;24:772-6.

Kaplan MM. Alanine aminotransferase levels: what's normal? Ann Intern Med 2002;137:49-51.

7 Tsai JF, Chuang LY, Jeng JE, Ho MS, Lin ZY, Hsieh MY, et al. Serum Tsai JF, Chuang LY, Jeng JE, Ho MS, Lin ZY, Hsieh MY, et al. Serum infections among blood donors. Liver 1997; 17:24-9.

8 Hung KY, Lee KC, Yen CJ, Wu KD, Tsai TJ, Chen WY. Revised cutoff values of serum aminotransferase in detecting viral hepatitis among CAPD patients: experience from Taiwan, an endemic area for hepatitis B. Nephrol Dial Transplant 1997;12:180-3.

9 Espinosa M, Martin-Malo A, Alvarez de Lara MA, Soriano S, Aljama P. High ALT levels predict viremia in anti-HCV-positive HD patients if a modified normal range of ALT is applied. Clin Nephrol 2000;54:151-6.

10 Ahn YO. Recent change in HBV carrier rate among Koreans. JAMA-Korea 1999:Sept-Oct:382-3.

11 Chun BY,Lee MK, Rho YK. The prevalence of hepatitis B surface antigen among Korean by literature review. Korean J Epidemiol 1992;14:54-62. (Accepted 28 January 2004)

doi $10.1136 /$ bmj.38050.593634.63

\section{Endpiece}

\section{Many a true word spoken in jest}

I am only a small cigarette, But my work I will get in, you bet, For the stern coffin maker

And the grim undertaker

Will declare I bring fish to their net. Everybody's book of jokes. London, 1890

Michael Warner, retired, Canterbury 